\title{
Eroze západních demokratických hodnot
}

\author{
Jiří Spousta \\ Západočeská univerzita v Plzni, Fakulta právnická
}

Anotace: Studie se zaměří na analýzu migrační situace ve vybraných zemích, resp. vybraných lokalitách (zde se bude konkrétně jednat o selekci dvou oblastí ve Velké Británii Londýn a Blackburn, Lancashire - s cilem analyzovat určité kriminologické a další negativní jevy a hledání jejich vzájemné korelace s ostatními kritérii struktury obyvatelstva) z hlediska ohrožení hodnotového rámce EU1 prostřednictvím tohoto migračního působení z asijských a afrických lokalit. V tomto ohledu bude zčásti navázáno na obsah předchozího sborníku „Právní stát ve světle evropských hodnot a ústavních garanci demokracie $v$ mezinárodní perspektivě“. S ohledem na problematiku tohoto „civilizačního střetu“ bude zkoumán

\footnotetext{
${ }^{1} Z$ hlediska tohoto příspěvku je na Velkou Británii stále ještě nahliženo jako na součást Evropské unie (s ohledem na opakované odložení konečného termínu pro odchod z 29. března 2019 na 12. dubna 2019 a poté na 31. ríijna 2019), a to i vzhledem k probíhajícím jednáním s cílem finalizovat podmínky vystoupení Velké Británie z Unie - tzv. „brexit“ - v užším slova smyslu, naopak v širšim kontextu je nutné podotknout, že volba dvou oblastí z Velké Británie i po jejím hypotetickém odchodu z Unie by nebyla zcela neadekvátní, nebot pro účely tohoto príspěvku je operováno s pojmem „hodnoty EU - hodnotový rámec EU“ jakožto se synonymem pro jakýsi „evropský kontext hodnot“, který nejenže je založen na židovsko-křestanských tradicích a hodnotách, ale také na dekádách a staletích společného vývoje a společné profilace $v$ rámci obdobného spektra důležitostních atributů, kterým my jakožto evropská civilizace přikládáme jistou hodnotovou míru.
} 
primárně vztah mezi procentuálním poměrem etnického složení obyvatelstva a jeho projekce do statistik trestné činnosti (opět s ohledem na vybrané skutkové podstaty) ve vybraných lokalitách. Tento analytický prístup si klade za cíl zejména odstranit politický aspekt této problematiky, a to včetně mediálního tlaku a lobbingu. Poté, co dojde k analýze vybraných lokalit na základě statistických údajů, přikročíme v závěru k posouzení, zdali je možné tento fenomén subsumovat pod problematiku tzv. "nestandardních bezpečnostních situací ve státě“ a zdali může Česká republika v budoucnu čelit do jisté míry identické nebo obdobné hrozbě - situaci. Studie bude zakončena prognostickou úvahou a návrhem řešení ústavního postupu jakožto možné reakce na danou situaci pro futuro.

Kličová slova: migrace, multikulturalismus, kulturní hodnoty, civilizační střet, hodnotový rámec $\mathrm{EU}$, kriminalita, útoky kyselinou, Blackburn, vztah majority a minority, etnické přečíslování, „The Great Replacement“, populační změna, právní řešení migračni situace, New York Declaration for Refugees and Migrants 2016, Global Compact on Refugees 2018

Abstract: This case study will focus on analysis of migration situation in selected countries, more precisely in selected locations (in this case, we will choose two main locations in Great Britain - London and Blackburn, Lancashire with one goal in mind, which will be to analyze certain criminology and other negative aspects, while searching for their mutual correlation with certain demographic attributes) in terms of its negative impact on EU democratic values throughout this migration process from Asian and African regions. In this regard, we will follow up on contents of the previous publication "The rule of law in the light of European values and 
constitutional guarantees of democracy in an international perspective". Regarding the problematic of the "clash of the civilizations", we will study mainly the relation between percentage values of ethnic composition and its projection into crime statistics (regarding only a few selected criminal offences) in our previously selected locations. This analytical approach was chosen mainly to avoid any political aspects of these issues, including influence of the media and lobbing. Once all presented statistics are analyzed and assessed, we will reach a final verdict, whether such situation warrants a classification as "non-standard state security risk“ and whether the Czech republic might in fact face an identical or similar threat in the future. The case study will be finished by a prognostic reasoning and by a proposition of a legal procedure(s), we might implement, in order to properly react to this situation in the future.

Keywords: migration, multiculturalism, cultural values, clash of civilizations, EU value framework, criminality, acid attacks, Blackburn, majority and minority coexistence, ethnic renumbering, "The Great Replacement", population change, legal solution of migration crisis, New York Declaration for Refugees and Migrants 2016, Global Compact on Refugees 2018 


\section{Úvod}

Eroze západních demokratických hodnot - pod tento pojem je možné subsumovat celou řadu právních i neprávních fenoménů. Náš exkurz se bude zejména ubírat cestou právně analytickou a zaměříme se na fenomén masové migrace, který nám bude sloužit jako hlavní kotevní struktura, jejiž některé negativní vnější projevy budeme bliže zkoumat a propojovat s rovinou právní, kde po zhodnocení statistických údajů budeme de lege ferenda představovat možná řešení a poukazovat na četná, na první pohled ne zcela patrná úskalí a hrozby, které tento fenomén migrace neoddělitelně provází.

Nežli se pustíme do analýzy samotného problému, úvodem bych velmi rád a velmi důrazně podotkl, že tato studie není $v$ žádném připadě namířena proti žádným skupinám obyvatelstva, kterými se zde budeme zabývat. Jelikož se studie dotýká pojmů jako multikulturalismus, migrace, kriminalita a jejich spojitosti, jedná se nejen o kontroverzní, ale také velmi citlivou oblast, a tudíž je naší povinností přistoupit ke zkoumání objektivních faktů zcela nestranně, ale také si uvědomit to, že lidský jazyk je formou komunikace ne zcela dokonalou a často vzniká propastný rozdil ${ }^{2}$ mezí tím, co řečník zamýšlel sdělit, co řečník opravdu sdělil, a tím, jak tato sdělená informace byla pochopená, připadně interpretovaná, což ve spojitosti s takto vyhroceným tématem představuje obrovskou míru zodpovědnosti. Jak už bylo řečeno, naším cílem bude celkové zhodnocení objektivní situace a hledání vhodných řešení z právní stránky - řešení, ze kterých bude

${ }^{2}$ Zde je namístě připojit i citát amerického autora Lestera del Reye: „Chybná interpretace je nejsmrtelnějši z lidských hříchů.“ 
moci těžit prospěch naše liberálně demokratická společnost jako celek, a pokud by chtěl někdo tuto studii interpretovat $v$ jakémkoliv jiném negativním smyslu namířeném proti etnickým menšinám, dopouštěl by se zavrženíhodného omylu, nebot' zde se jedná pouze o velmi jednoduchou operační metodiku na principu: identifikace problému - zhodnocení relevantnosti problému - navržení vhodných právních řešení - společenský diskurz s cílem pokusit se o hlubší pochopení tohoto fenoménu a nalezení či pokus o dosažení společenského konsenzu, který jistě patři mezi neodmyslitelné prvky moderní demokracie.

V rámci této případové studie se zaměříme na analýzu migračni situace ve vybraných zemích EU (primární pozornost bude věnovaná Velké Británii, ale $v$ určitých souvislostech zmíníme i Irsko, případně Španělsko aj.), resp. ve vybraných lokalitách EU (Londýn a Blackburn, Lancashire ve Velké Británii). V návaznosti na samotný název této studie „Eroze západních demokratických hodnot" bude pozornost věnována především jednomu aspektu migrace - tímto aspektem je: vliv, resp. působení fenoménu migrace na hodnotový rámec EU (toto působení bude demonstrováno zejm. $v$ trestněprávní rovině - zde se budeme zabývat nárůstem trestní činnosti, ale také specifickými „novými“ skutkovými podstatami nebo, lépe řečeno, způsobem provedení trestní činnosti, který není zcela typický pro oblast euroregionu, nicméně je nutné podotknout, že $v$ této oblasti docházi k průniku rovin trestního práva, ústavního práva, ale i práva evropského, pokud bychom chtěli setrvat na typické akademické distinkci jednotlivých teoreticko-právních oborů, a těmto rovinám bude taktéž věnována pozornost s ohledem na hodnocení 
dopadů tohoto migračního působenî). Cílem této studie tedy bude hledání souvislostí mezi nárůstem trestní činnosti ${ }^{3}$ v určitých oblastech a etnickým složením obyvatelstva těchto regionů - jakožto finálního projevu vlivu masové migrace.

Jelikož se nejedná o jednoduchý dvourozměrný problém, ve zkratce nastíním postup, jaký byl zvolen a v rámci jakého bude práce koncipována. Struktura analýzy byla zvolena následovně:

(i) V první řadě bylo navázáno na předchozí sborník s názvem „Právní stát ve světle evropských hodnot a ústavních garancí demokracie $v$ mezinárodní perspektivě“, a to konkrétně na kapitoly:

a) „EVROPSKÉ HODNOTY A ÚSTAVNI GARANCE PRÁVNÍHO STÁTU - POZNÁMKA K MATERIÁLNÍMU OHNISKU ÚSTAVY“ - autorkou je doc. JUDr. Monika Forejtová, Ph.D.,

b) „OCHRANA LIDSKÝCH PRÁV JAKO HODNOTA EVROPSKÉ UNIE“ - autorem je doc. Mag. phil. Dr. iur. Harald Christian Scheu, Ph.D.,

c) „ZÁPADNÍ PRÁVO A MULTIKULTURNÍ VÝZVY“ - autorem je doc. JUDr. PhDr. Pavel Maršálek, Ph.D.

\footnotetext{
${ }^{3}$ Zde je opět nutné zdůraznit, že v této fázi neni prosazována teze, ze které by vyplývalo, že migrace je hlavním či snad jediným důvodem nárůstu kriminality v určitých regionech. Cílem je zejména hledání souvislostí a korelaci mezi stavy migrace a růstem trestné činnosti. Jak již bylo zmíněno, nejedná se o jednoduchou problematiku, kterou by bylo možné trivializovat a tím se dopustit nepřesných či zavádějících tvrzení. Do sféry vlivu také vstupuji faktory jako chudoba, otázka sociální péče a sociálního zabezpečení ze strany státu, preventivní činnost v sektoru prevence kriminality, nasazení a efektivita a modus operandi policejních a jiných pořádkových jednotek, př́padně také úloha justičního a vězeňského systému $v$ dané zemi, legislativa, mezinárodní vztahy a celá řada dalších činitelů, které musíme mít trvale na paměti.
} 
(ii) Následně bude zhodnocena současná situace (případně situace historická v případě, že absentuji přesné statistické údaje a $k$ dispozici jsou pouze předpokládané predikční odhady možného vývoje).

- Zde bude uplatněna snaha se vyhnout politickému aspektu této situace, a to včetně lobbingu.

- Dále bude eliminován negativní mediální vliv, který se velmi často manifestuje $v$ podobě zastírání skutečných podstat problémů věcí a šiření nepravdivých informací.

- Prípadová studie se nebude zabývat ani vymezením a definicí jednotlivých „hodnot"“, připadně ani snahou o vymezení jejich vzájemné pozice v ústavněprávním systému za použití a uplatnění principu proporcionality apod.

- Na současnou situaci bude nahliženo primárně ze statistického hlediska.

(iii) Jádrem studie pak bude odpověd' na otázku, „zdali se jedná o nestandardní situaci“", a to včetně možných prognóz vývoje tohoto fenoménu a zamyšlení nad tím, jak je možné na tuto situaci reagovat, at už v rámci ústavního, nebo jiného alternativního postupu.

\footnotetext{
${ }^{4}$ Snaha vyhnout se vzájemnému poměřováni a vymezováni jednotlivých hodnot je odůvodněna určitou terminologickou nejasností, o které hovoři doc. Mag. phil. Dr. iur. Harald Christian Scheu, Ph.D., ve svém přispěvku, viz FOREJTOVÁ, Monika. Právni stát ve světle evropských hodnot a ústavních garanci demokracie $v$ mezinárodní perspektivě. Plzeň: Západočeská univerzita v Plzni, 2018, s. 67. ISBN 978-80-261-0859-7. Tato terminologická nejasnost se podle něho týká vztahů hodnot a principů a dodává, že podle čl. 2 SEU mezi hodnoty patři (1) lidská práva, (2) demokracie a (3) právní stát; zatímco podle preambule Listiny základních práv EU jsou hodnotami (1) lidská důstojnost, (2) lidská svoboda aj., zatímco demokracie a právní stát jsou považovány za principy.
} 


\section{Hlavní otázka tedy zní:}

\section{„Ohrožuje migrace a jevy s ní spojené v současné podobě nějakým zpưsobem hodnotový rámec $E U^{5}-$ západní liberálně-demokratické hodnoty?‘}

Aspekty střetu východního myšlení se západním právním systémem se zabývá i doc. JUDr. PhDr. Pavel Maršálek, Ph.D., který si klade otázku, zdali je možné docílit mezikulturní shody, a dále konstatuje, že "co se však stane skutečností, odhalí až zítřek".6 Poslední pointou tohoto příspěvku, kterou zde $v$ úvodu nastíním, je tedy mimo jiné $\mathrm{i}$ částečně reagovat na toto tvrzení otázkou, zdali „zítrek nenastal již dnes“, a to vzhledem $k$ poměrně explicitním statistikám, které máme $\mathrm{k}$ dispozici a $\mathrm{z}$ nichž některé budou $\mathrm{v}$ této práci také prezentovány.

\section{Migrace - multikulturalismus jako civilizační střet, nebo krajní případ selhání integračního úsilí?}

Jak již bylo naznačeno, modus operandi naši analýzy bude založen na statistické analýze etnického složení a následném hledání spojitostí mezi etnickým složením a nárůstem či snižováním kriminality v určitých vybraných oblastech.

\footnotetext{
${ }^{5} \mathrm{~V}$ textu bude přistupováno k pojmům „hodnotový rámec EU“ a „západní demokratické hodnoty“ jako k pojmům obdobného významu, a to pouze pro účely tohoto příspěvku (pozn. autora).

${ }^{6}$ FOREJTOVÁ, Monika. Právni stát ve světle evropských hodnot a ústavních garanci demokracie v mezinárodni perspektivě. Plzeň: Západočeská univerzita v Plzni, 2018, s. 67. ISBN 978-80-261-0859-7.
} 
Nežli ale přikročíme $\mathrm{k}$ samotnému zkoumání statistik, je třeba definovat určité aspekty této problematiky a odpovědět na předchozi otázku, zdali migrace ${ }^{7}$ vystupuje v určitých ohledech jako jakýsi negativní faktor.

\subsection{Počet migrantů se zvyšuje, a to geometrickou řadou i přes četná omezení}

I když se v některých regionech podařilo přes četná opatření přiliv migrantů omezit a regulovat, neznamená to, že příchod těchto osob do evropského regionu se zcela zastavil. Můžeme hovořit jednak o přímém navýšení prostřednictvím přechodu státních hranic a jednak o sekundárním navýšení prostřednictvím narozených potomků na území států euroregionu, tzn. „druhá generace“ usídlených přistěhovalců. Na jedné straně figuruji razantní omezení nelegální migrace, na druhé straně v některých zemích sílí úsilí o podporu legální migrace, zde můžeme zmínit např. irskou iniciativu Project Ireland 2040, která předpokládá navýšení populace Irska v následujících 20 letech o více než 1 milion $^{8}$, což je poměrně vysoké číslo, uvážíme-li, že populační stav Irska v roce 2017 byl 4,784 milionu obyvatel. Vzhledem ke klesající porodnosti, která v roce 2017 měla index 1,97 narozeného dítěte na jednu matku a jeho následnému poklesu $v$ roce 2018 , a to i s uvážením, že pouze 78 \% narozených dětí se narodí matce s irským občanstvím, Ize předpokládat, že populační číslo 4,784 milionu obyvatel

\footnotetext{
${ }^{7}$ Mějme na paměti, že zde hovořime o migraci masové a zejm. migračních vlnách z afrických a asijských regionů, primárně z oblasti Blízkého východu (pozn. autora).

${ }^{8}$ Project Ireland 2040. Gov.ie [online]. 2019 [cit. 2019-09-16]. Dostupné z: https:// www.gov.ie/en/campaigns/09022006-project-ireland-2040/?referrer=/en/project -ireland-2040
} 
neporoste, ale spiše se bude snižovat ${ }^{9}$, a to zejména jeho poměrná část tvořená původním irským obyvatelstvem, což znamená, že v roce 2040 může situace být taková, že každá pátá osoba v Irsku nemusí být irským občanem. Tento případ Irska zde uvádím zejména proto, že na základě některých informací se může fenomén migrace jevit jako „cosi, co odeznělo" po implementaci radikálnějších opatření ze strany EU a zvýšení kontroly vnějších hranic. $\mathrm{K}$ nahlédnutí přikládám statistiky Rady Evropské unie, které mohou budit poněkud zavádějící dojem, jak jsem již poznamenal výše, informace zde prezentované umístují do popředí statistiku o $90 \%$ poklesu ${ }^{10}$ nelegálních vstupů mezi léty 2015 a 2019, kdy se celkový počet nelegálních vstupů vyšplhal na neuvěřitelných 1046336 nelegálních vstupů v r. 2015 a pouhých 35000 $\checkmark$ roce 2019 (toto číslo zahrnuje pouze údaje do června r. 2019). Pouze s ohledem na tuto statistiku a tato čísla bychom mohli konstatovat, že migrační vlny skončily a není nutné se touto problematikou dále zaobírat, nicméně k přikladu Irska přiřad'me ještě Velkou Británii, kde čistá migrace, tzv. „net migration" kulminovala v červnu r. $2018^{11}$ a dosáhla desetiletého maxima, kde hovoříme o čisté migraci ze zemí mimo EU, která se bližila číslu 250 000. Jak je tedy patrné, problematika

${ }^{9} \mathrm{CSO}$ statistical publication, 31 August 2018, 11am: Vital Statistics Quarter 12018. Cso.ie [online]. 2019 [cit. 2019-09-16]. Dostupné z: https://www.cso.ie/en/releasesand publications/ep/p-vs/vitalstatisticsfirstquarter2018/

${ }^{10}$ Infografika. Migračni toky: trasa přes východní, centrální a západní Středomoří. Evropská rada: Rada Evropské unie [online]. 2019 [cit. 2019-09-26]. Dostupné z: https://www. consilium.europa.eu/cs/infographics/eastern-and-central-mediterranean-routes-09-2017/. Migrační politika EU. Evropská rada: Rada Evropské unie [online]. 2019 [cit. 2019-09-16]. Dostupné z: https://www.consilium.europa.eu/cs/policies/migratory-pressures/ ${ }^{11}$ Migration Statistics Quarterly Report: November 2018. Office for national statistic [online]. 2018 [cit. 2019-09-16]. Dostupné z: https://www.ons.gov.uk/peoplepopulation andcommunity/populationandmigration/internationalmigration/bulletins/migrations tatisticsquarterlyreport/november2018 
migrace působí v komplexnějších vztazích a statistiky je nutné vyhodnocovat $v$ širším kontextu. Posledním příkladem, na který poukážu, $v$ této kapitole jsou data vytažená z posledních dvou velkých cenzů - resp. sčitání obyvatelstva ve Velké Británii (cenzy se ve Velké Británii konají každých 10 let, doposud byly realizovány mj. v letech 2001 a 2011, následující sčítání obyvatelstva proběhne v r. 2021). Zde je nejmarkantnější rozdíl, pokud porovnáme procentní nárůst jednotlivých etnických skupin mezi léty 2001 a 2011. Původní bělošské obyvatelstvo zaznamenalo populační nárůst $1,70 \%$, zatímco skupina „nezařazených Asiatů“ zaznamenala nárůst $247,98 \%$, přičemž obyvatelstvo asijského původu jako celek zaznamenalo nárůst 69,58 \%, a to z 2578826 obyvatel na 4373339 obyvatel, a černošská minorita také zaznamenala nárůst, z 1148738 obyvatel v r. 2001 na 1904684 obyvatel v r. 2011, což činí zhruba $65,80 \%$ nárůst ${ }^{12}$. Opět je tedy patrné, že migrační vlny jsou schopny v rámci desetiletého rozpětí velmi zásadně změnit etnické uspořádání ve státě.

Proč bychom se tedy měli touto problematikou zabývat? Výše jsem demonstroval aktuálnost problému a také to, že tento fenomén migrace $s$ přihlédnutím ke všem okolnostem v dohledné době nevymizí - doc. JUDr. PhDr. Pavel Maršálek, Ph.D., význam tohoto fenoménu nadsazuje tím, že ho definuje jako nejvýznamnější případ multikulturalismu v právu ${ }^{13}$.

\footnotetext{
${ }^{12} 2011$ Census: Ethnic group1, local authorities in the United Kingdom. Office for National Statistics [online]. (C2019 [cit. 2019-09-17]. Dostupné z: http://www.ons. gov.uk/ons/rel/census/2011-census/key-statistics-and-quick-statistics-for-localauthorities-in-the-united-kingdom---part-1/rft-ks201uk.xls

${ }^{13}$ FOREJTOVÁ, Monika. Právní stát ve světle evropských hodnot a ústavních garancí demokracie v mezinárodní perspektivě. Plzeň: Západočeská univerzita v Plzni, 2018, s. 62. ISBN 978-80-261-0859-7.
} 


\subsection{Problematičnost situace - klíčové rysy}

Druhým aspektem, který vystupuje do popředi, pokud hovoříme o vlivech migračních působení, je kromě neustále se zvyšujícího počtu migrujících osob i jistá problematičnost situace, kterou se pokusíme rozčlenit do několika klíčových bodů. Pojem „problematičnost“ může, díky své negativní konotaci tohoto výrazu, působit částečně neadekvátně, nebot $v$ této kapitole budou zařazeny i jisté kulturní odlišnosti a je nutné do určité míry diferencovat mezi tím, co je odlišné, a tím, co bychom označili jako „problematické“ či špatné. Zde totiž narazíme na odlišnosti kulturní, náboženské, právní i sociologické, a to mezi oblastí našeho euroregionu a oblastmi, ze kterých přichází většina migrujícího obyvatelstva, nebot' se jedná ve velké míre o země islámské. Jordan Peterson, Ph.D., například uvádí dvě hlavní roviny ${ }^{14}$ polarizace mezi islámem a naši kontinentální kulturou, které podle něho vystupuji do popředí; v první řadě jde o aspekt odluky státu a církve, tedy stupeň sekularizace, resp. její absence ve sféře islámského práva, a dále např. poukazuje na expanzivní charakter islámské kulturní domény, kde označuje proroka Mohameda pojmem „war lord“, což nehledě na kontroverzní charakter takovéhoto tvrzení s ohledem na reakce, které toto tvrzení vyvolalo, profesor Peterson odůvodňuje historickými událostmi, které v průběhu cca 600 let daly do pohybu takové unifikační procesy, které na Blízkém východě vytvořily jedno z nejmocnějších impérii - tím má na mysli státní útvary tohoto regionu, které pod záštitou islámské expanze vyvrátily středověkou Byzanc, což do značné míry otráslo

${ }^{14}$ Jordan Peterson - on Islam. Youtube.com: video [online]. 2017 [cit. 2019-09-16]. Dostupné z: https://www.youtube.com/watch?v=5yjdl3a-eRw 
západním křestanským světem a předznamenalo další staletí válečných konfliktů mezi křestanskou Evropou a východním „islámským impériem“. V dnešním globálně propojeném a propleteném světě se střetávají a potkávají všechny přední světové náboženské a ideologické směry, profesor Peterson pak závěrem dodává, že s ohledem na vzájemné vztahy těchto náboženských systémů je možné nalézt více společného mezi systémy křestanství a buddhismu, případně taoismu, zatímco hledání jakéhosi překlenutí mezi kulturou křestanskou a tou islámskou zůstává stále výzvou pro budoucí badatele, religionisty, teology a právníky.

Zde opět můžeme navázat na doc. JUDr. PhDr. Pavla Maršálka, Ph.D., který uvádí také několik důvodůำ, proč úsilí o dosažení harmonického multikulturalismu mohou být problematičtější, než se původně předpokládalo, a také proč integrační úsilí může ve výsledné fázi poměrně rapidně implodovat. Tyto důvody můžeme tedy uspořádat takto:

(i) Malá slučitelnost obou kultur, pod kterou můžeme subsumovat tato kritéria:

a. neuznávání rovnosti mužů a žen,

b. neuznávání ženské autonomie (což často vede $k$ nuceným sňatkům),

c. zločiny ze msty,

d. pokusy o rozšiřování náboženských symbolů do škol (oděv, burka apod.),

e. odmítání práva na ochranu zvírat (rituální oběti),

${ }^{15}$ FOREJTOVÁ, Monika. Právni stát ve světle evropských hodnot a ústavních garancí demokracie v mezinárodní perspektivě. Plzeň: Západočeská univerzita v Plzni, 2018, s. 63. ISBN 978-80-261-0859-7. 
f. nárůst kriminality - což budeme zkoumat blíže pomocí statistik (který má svůj pưvod v nízké zaměstnanosti a chudobě přistěhovalcư, ve vyhrocenějších prípadech pak dochází $k$ eskalaci na úroveň organizovaného zločinu - $v$ naší studii budeme věnovat pozornost $i$ tzv. "moped gangs“ a $v$ těch nejkrajnějších prípadech se jedná o eskalaci až na úroveň terorismu).

(ii) Do druhého rozměru diferenciace bychom mohli zařadit aspekty, které maji hlubší náboženskou spojitost - zejm. fakt, že islámská kultura je postavena na rozhodujícím vlivu náboženství na organizaci a chod společnosti. Do této sféry můžeme subsumovat:

a. suverenitu boha,

b. neuznávání odluky státu a církve, popř. věřících (o kterém jsme již hovořili),

c. právo je zde náboženské povahy (tzn., že ignoruje elementární lidskoprávní standardy a tímto se dostává do konfliktu s tradičními liberálně-demokratickými hodnotami - zejm. s respektem ke svobodě a nezadatelným, nezcizitelným, nepromlčitelným a nezrušitelným lidským a občanským právům, která představuji fundamentální základ našeho kulturního dědictví nejen $v$ rámci evropského regionu),

d. společná náboženská víra je založená na posvátném textu (ten na rozdíl od běžných, prípadně $i$ rigidních ústavních zákonů nemůže být nikdy měněn, mimo to je zde převažující vztah ze strany podřizenosti vůči takovémuto náboženskému textu, nikoliv vztah dodržování práv a uznaných svobod). 
Zde jsme si tedy ve stručnosti vymezili některé aspekty, které mohou představovat nepřekonatelnou výzvu v cestě za představou rozmanité multikulturní společnosti, kde $v$ rámci jedné komunity by se lidské bytosti zde žijici oprostily od těchto rozdílů a vytvořily efektivně fungující pospolitost občanů, kde dojde $\mathrm{k}$ harmonickému vyvážení všech úrovní práv a svobod. Je ale nutné podotknout, že rozdílnost se netýká jen a pouze primárně náboženství. Na náboženský systém bych nahližel pouze jako na jeden ze základních piliřů společnosti, který pomáhá formovat kulturu a smýšlení lidí, kteři se vyskytuji $v$ určitých regionech naši planety. Zde bych tedy závěrem poznamenal, že aspektem, který může pro nás představovat daleko větši riziko nežli důvody výše jmenované, může být "forma smýšleni" určitého procenta migrujícího obyvatelstva, kterou bych definoval tím, že tkví v „automatické nárokovatelnosti“, kde by se samožrejmě dala vést polemika, do jaké míry je tento přistup založen a ovlivněn náboženským vyznáním. Tento pojem bych demonstroval na príkladu žadatelství o azyl, což je jedním ze základních politických práv, kdy na základě okolností má každý právo žádat azyl, každý však již nemá automaticky garantované právo, aby mu byl azyl automaticky udělen, např. české ústavní právo včlenilo do obsahu Listiny základních práv a svobod, článku 43 , omezující klauzuli, která při jednání v rozporu se základními lidskými právy a svobodami znamená automatické odeprení udělení azylu. $V$ prípadě príchodu migrantů na naše území a následného odmítnutí udělení azylu by se pak tento prístup uplatnil $v$ jejich nepochopení a rozhořčení nad tímto odmítnutím, nebot z pohledu „automatické nárokovatelnosti“ pojmy „právo o něco žádat" a „právo na získání takovýchto materiálních statků či jiných výhod" zcela splývá v jeden totožný pojem. 
Alternativním príkladem pak může být rétorika ${ }^{16}$, kde na položenou otázku, ,jak můžete ospravedlnit svoje kriminální chováni“", člen organizovaného zločinu odpovídá takto: „Chci to, co mají ostatní lidé, tak si to vezmu, ale je to $v$ podstatě $v$ pořádku, protože neokrádám každého člověka $v$ Londýně, beru si jen to, abych dosáhl denního výdělku, poté si dám pauzu a pokračuji až další den." Jde tedy o velmi primitivní formu uvažování, která byla typická pro starověké předstátní kmenové pospolitosti, kde otázka vlastnictví byla rigidně spojena s otázkou aplikace síly - tedy materiální statky si přisvojila silnější strana na úkor té slabší.

Za protipól k této "nárokovatelnosti“ bych označil jakousi „automatickou garanci solidarity“ ze strany státu, která může sama o sobě dosáhnout vyšší míry destruktivní úrovně nežli kulturně odlišný myšlenkový postoj příchozi masy obyvatelstva na území jiného státu. At' už jsou důvody $k$ tomuto přistupu ukotvené $v$ historických souvislostech a extrémně rigidní snaze oprostit se od morálněprávního selhání evropského vývoje 2. pol. 20. st., nebo dané současnými proudy neoliberalismu a aktivismu lidských práv, můžeme tyto projevy diferencovat do dvou rovin, ve kterých se tento přistup manifestuje. První rovinou by byla rovina primárně ekonomická (finanční podpory, příspěvky, dávky apod.) ve sféře, kterou v rámci ústavního práva klasifikujeme jako skupinu práv hospodářských, sociálních a kulturních, zejm. pak právo na pomoc $v$ hmotné nouzi, a to s cílem zajistit základní životní podmínky, všeobecnou ochranu zdraví aj. Druhou rovinu představuje ne zcela taxativně vymezená množina

${ }^{16}$ Look Inside Britain's Moped Crime Gangs. Youtube.com: video [online]. 2019 [cit. 2019-09-16]. Dostupné z: https://www.youtube.com/watch?v=LECDoOLk02c 
procesů, které v duchu konformity cílí jednak na odmítnutí konfliktního postoje a jednak na dosažení maximální úrovně symbiotického multikulturního soužití za použití metod politické korektnosti, zatímco se snaží o odstranění a eliminaci xenofobního působení a rasistických projevů. Jak již bylo zmíněno, jedná se o široké spektrum působení, např. snahy o odstranění křestanských náboženských symbolů z objektů, kam byly relokovány skupiny migrantů ${ }^{17}$, odmítnutí vyvěšení národní vlajky ve dnech státních svátků a dalši jiná „konformně-vyvažovaci“" opatření s cílem vyhnout se kulturnímu střetu.

Zde se naposledy vrátíme ke studii doc. JUDr. PhDr. Pavla Maršálka, Ph.D., který závěrem dodává18 ${ }^{18}$ že v poslední době sílí přesvědčení, že představa o multikulturní společnosti je pouhou utopií, a to zejm. díky velkým kulturním rozdílům, vzniku a rozrůstání sociálně vyloučených ghett ( $v$ angl. též označována jako tzv. „no-go zones“), nárůstu chudoby, kriminality a eventuálně i náboženského fundamentalismu. Problematika vzniku ghett úzce souvisí s problematikou etnické homogenizace a tzv. „enklavizace“, což ve svém finálním důsledku má za následek přečíslování a vytlačení původního obyvatelstva, tedy nahrazení původního obyvatelstva obyvatelstvem novým, což je z historického pohledu velmi obvyklým jevem. Pokud se budeme zdržovat na území Anglie, připomeňme migraci kmenů Anglů, Jutů a Sasů v 5. st. n. I., kteři se $v$ následujících stoletích stali dominantní kulturní

\footnotetext{
${ }^{17}$ Norway's call to remove crosses causes backlash. The local no [online]. [cit. 201909-16]. Dostupné z: https://www.thelocal.no/20151130/norway-remove-cross-refugees ${ }^{18}$ FOREJTOVÁ, Monika. Právni stát ve světle evropských hodnot a ústavních garanci demokracie v mezinárodní perspektivě. Plzeň: Západočeská univerzita v Plzni, 2018, s. 65 . ISBN 978-80-261-0859-7.
} 
silou, což vyústilo v úpadek keltské civilizace a následné podmanění Anglie Normany r. 1066. V dnešní době se tato „enklavizace“ projevuje spíše skrze postupný, pliživý a graduální posun. Město Blackburn v hrabství Lancashire, zhruba 33 mil severně od Manchesteru se v tomto ohledu stane brzy učebnicovým příkladem selhání integračních úsilí a neoapartheidu a můžeme zde převést do praxe všechny body, které zmiňuje doc. Maršálek. Ačkoliv poměr etnických skupin na základě posledního cenzu z r. 2011 zůstává v poměru $2: 1$ ve prospěch původního obyvatelstva, v průběhu desetiletí, mezi roky 2001 a 2011, došlo ke čtyřnásobnému nárůstu ${ }^{19}$ počtu etnicky diverzifikovaných skupin v této oblasti a došlo k faktickému rozdělení města na jakousi „muslimskou“ část a na část, kde se soustřed'uje původni obyvatelstvo. Město následkem těchto vlivů muselo čelit značnému politickému radikálnímu tlaku a $v$ důsledku také násilným pouličním nepokojům. Současné statistiky ukazují, že Blackburn nebude posledním takovým příkladem.

\subsection{Rozrušování hodnotového rámce}

Předchozí kapitoly nastínily existenci dvou základních elementů a těmi jsou v kapitole 1.1 existence samotného fenoménu masové migrace a v kapitole 1.2 klíčové aspekty odlišnosti kultur, smýšlení a také jisté sféry možných kolizí takovýchto odlišností. Zde se zaměříme již na samotný produkt - na samotnou potenciální „erozi“ či narušení našeho západního evropského kulturního a právního rámce, a to za předpokladu,

${ }^{19}$ Blackburn White Fright Divided Britain. Youtube.com: video [online]. 2018 [cit. 201909-16]. Dostupné z: https://www.youtube.com/watch?v=RUmiCS-gRQs 
že budou kumulativně splněny podmínky ze dvou předchozích kapitol, tj., že dojde k relokaci většího počtu obyvatelstva a následně vlivem odlišnosti kultur obyvatelstva relokovaného a obyvatelstva původního dojde ke kolizi zájmů.

Samotné rozrušování hodnotového rámce naší kontinentální právní kultury bych spatřoval zejména $v$ těchto rovinách:

a) Pokud hovoříme o migračních vInách z oblastí afrických regionů a regionů Blízkého východu, sledujeme zde silné uplatnění principu personality práva, tzn., že tyto osoby si s sebou doslova „přinášejí svoje právo a jiné kulturní zvyklosti“, což se v praxi může promítnout do oslabení působnosti práva původního, a to zejm. tím, že nově usazené obyvatelstvo bude odmítat svrchovanost práva kontinentálního a nadále bude aplikovat právo svoje, což může znamenat docela citelný zásah do práv osobní svobody, rovnosti mezi muži a ženami, výkonu zvykového trestního práva uvnitř uzavřených komunit, kde se vytvoři vlastní hierarchické uspořádání spolu $s$ metodami vynucování tohoto zvykového práva, a to například včetně mrzačicích a jiných trestů, jejichž uložení a výkon by nepřipadalo dle kontinentální právní kultury v úvahu.

b) Prostřednictvím radikalizujících se skupin (a to i $v$ rámci politického spektra politicky aktivních skupin) se do popředi mohou dostat extremistické nacionalistické strany, což může být přisuzováno neadekvátnímu postupu ze strany státu při řešení těchto migračních výzev, tuto hrozbu bych klasifikoval jakožto vznik 
sekundárniho rizika, a to jako nárůst polarizace politického spektra, včetně nárůstu podpory extremistických skupin, kde se velmi často setkáváme s „černobílou“ rétorikou „Kdo je s námi?“ - „Kdo je proti nám?“ (v angl. "Who is with us?" - "Who is against us?").

V terciární rovině pak dochází už přímo k ovlivňování státního aparátu a veřejně činných složek ve státě těmito zradikalizovanými politickými skupinami, a to jejich prímou participací na výkonu veřejné moci ve státě, pokud získaji ve volbách dostatečný počet hlasů, překonají uzavírací klauzuli a stanou se tak přímo participujícím subjektem bud' v orgánu moci zákonodárné, nebo $v$ rámci územní samosprávy, což může vést ještě $\mathrm{k}$ hlubšímu prohloubení situační nestability a zvýšené míre polarizace.

c) Pokud situace nebude řešena efektivně a preventivně, Ize předpokládat následnou eskalaci, která si vyžádá boj nekonvenčními prostředky ze strany státu; určitou paralelu zde můžeme vysledovat s legislativními opatřeními realizovanými ve Spojených státech amerických po útocích z 11. záŕi 2001, kde ve smyslu doktriny „nulové tolerance“ a zásady, že „účel světí prostředky“, došlo k výrazným zásahům do sféry demokratických zásad a základních lidských práv, a to např. práva na ochranu před neoprávněnými zásahy do soukromého a rodinného života, připadně práva na ochranu před neoprávněným shromažd'ováním a jiným zneužíváním údajů o své osobě nebo zásahům do nedotknutelnosti osoby ( $k$ aplikaci těchto prostředkủ by docházelo např. v boji proti organizovanému zločinu, který je velmi spjat s fenoménem ghettoizace). 
d) Možná největším rizikem rozrušení evropského hodnotového rámce může být cesta samotné legality, která, byt je dnes již neodmyslitelným pilírem moderních demokratických států, může představovat i skrytou hrozbu v podobě prosazení nelegitimních cílů vládnoucími elitami, které, byt̉ byly zvoleny prostřednictvím reprezentativní demokracie do pozic zákonodárných a ústavodárných, přestaly jednat ve smyslu zásad materiálního demokratického právního státu (jinak řečeno, prostřednictvím přečíslování, resp. nahrazením původního obyvatelstva obyvatelstvem cizím - at' už $v$ prímé podobě prostřednictvím masové migrace, resp. relokace, anebo $v$ neprímé podobě kombinací nízké porodnosti pưvodního obyvatelstva a vysoké hranice porodnosti obyvatelstva nově usazeného -, uplatněním volebniho práva, získáním potřebné většiny $v$ zákonodárných orgánech a ve výsledné fázi prosazením zákonodárství, které nebude zcela slučitelné se západními demokratickými hodnotami - zde se může jednat o zákonodárství, které se odchýlí od zásady rovnosti před zákonem a plynule přejde do roviny pozitivní diskriminace, kde ve výsledné fázi může dosáhnout i takové úrovně, že ochromi justični systém dané země, případně jiné složky vnitřní bezpečnosti s cilem dosáhnout rovnosti a diverzity ${ }^{20}$ ve všech možných úrovních).

\footnotetext{
${ }^{20}$ Pozornost bychom mohli zaměřit na vládní dokument, který vznikl pod záštitou Davida Lammyho, bývalého britského ministra pro inovace a člena vládní skupiny pro násilnou kriminalitu, a který mezi své stěžejni principy včleňuje snahu o odstranění nízké úrovně etnicky diverzifikovaného zastoupení mezi složkami justičního, vězeňského a bezpečnostního aparátu, což označuje jako jeden z kličových problémů kultury, která je vymezená jako „my a oni“, a vytváŕi tak nepatřičnou diskriminačni bariéru (zde by
} 
e) Další projev rozrušení struktury hodnotového rámce euroregionu může představovat i přistoupení a ratifikace mezinárodních smluv a paktů, které postaví zájem většiny nad zájem jednotlivých svrchovaných států i přesto, že podstata takovýchto instrumentů a dokumentů je částečně postavená na vzdání se části práv v rámci státní sféry vlivu, a jejich přenos na nějakou mezinárodní entitu. Zde máme na mysli zejm. dokumenty, které mohou prímo způsobit eskalaci výše jmenovaných aspektů migrace tím, že se státy zavážou plnit závazky z těchto mezinárodních smluv, $\mathrm{k}$ jejichž úspěšnému plnění nemají ekonomické ani jiné prostředky, což může vyústit v neřiditelnou migraci, která nebere ohled na formální stránku procesu integrace, nýbrž na první místo staví ono plnění závazku, zejm. dosahování číselných kvót, a to aniž by bylo dostatečně zajištěno zázemí pro migrující obyvatelstvo a byl k dispozici proškolený personál, který je připraven reagovat na prípadná nedopatření a výzvy (nepřimo tak může dojít $k$ oslabení stupně ochrany lidskoprávního rámce občanů daného státu s cílem posílit lidskoprávní ochranu migrujíciho obyvatelstva). Příkladem by pak mohl být tzv. Global Compact for Migration.

dle tohoto reportu byla doporučena strategie, která by zvýšila etnickou rozmanitost zastoupení $v$ řadách soudců a dalšich úředníků spojených s výkonem funkce $v$ rámci soudní moci - pokud bychom tento myšlenkový postup velmi zjednodušili a interpretovali téměř až ad absurdum, bylo by možné konstatovat, že by se aplikaci těchto principů justični systém přeměnil ze systému založeného na kvalifikačních předpokladech na systém založený na etnické rozmanitosti, což se samo o sobě stává kontraproduktivním $v$ tom smyslu, že pokud se snažíme o odstranění rámce - přístupu „my a oni“ -, tím, že se systém přeměni na sféru, kde bude konstantě kontrolován \% stav zastoupení všech etnik, dosahujeme částečně prímého opaku), tzv. Lammy review: final report. Gov.uk [online]. 2017, s. 6 a 31 [cit. 2019-09-16]. Dostupné z: https://www.gov.uk/government/ publications/lammy-review-final-report 
f) V neposlední řadě pak zmiňme i úpadek role a postavení mezinárodních institucí a organizací, které Ize považovat jako sdružení států založených na určitých hodnotách, např. NATO nebo EU.

V připadě EU vystupuje do popředí otázka vystoupení Velké Británie z Unie a není to náhoda, že naše studie se primárně zaměřuje na oblast Velké Británie, kde v posledních cca deseti letech situace spojená s migrací, nárůstem kriminality a aspekty problematiky integrační politiky dosáhla neudržitelného stavu ( $v$ tomto ohledu byla masová migrace spojována se selháním evropské azylové politiky a selhání EU jako celku $v$ tomto ohledu a jedním z mnoha propagačních důvodů pro vystoupení z EU se stalo úsilí o obnovu kontroly hranic a omezení volného pohybu osob).

\section{2 „Battlefield London“ - případová studie (analýza stavu kriminality v návaznosti na migrační působení lokality na základè statistických údajů)}

Pro účely této studie budeme porovnávat statistiky migračních vin a nárůstu kriminality, a to nikoliv s cílem zcela jednoznačně identifikovat masovou migraci jako jediný nebo hlavní faktor \% nárůstu kriminality, nýbrž jakožto vztah mezi dvěma elementy (masovou migrací na jedné straně a nárůstem kriminality na straně druhé), mezi kterými je možné hledat určitý stupeň korelace. V případě Londýna vystupuji do popředí tři hlavní oblasti projevu zvýšené úrovně kriminality a jedná se o: (1) tzv. „moped crimes“ (naplnění skutkové podstaty trestného činu loupeže, pokud bychom 
takovéto jednání posuzovali podle českých trestněprávních předpisů, a to ve formě pouličního prepadení, kde útočníci využívaji velké mobility malých motorek a skútrů $k$ vytvoření momentu překvapení oběti a dochází $i$ k uplatnění násilí vưč poškozené osobě v prípadě jakéhokoliv odporu za použití středně dlouhých sečných a bodných zbraní - mačet, kukri nožů apod.); (2) tzv. „knife crime“ (zde bychom hovořili o paralele s trestnými činy § 140, § 141, § 145, § 146, § 158, $\S 173, \S 185, \S 186, \S 358$ a prípadně jiné skutkové podstaty, pokud bychom chtěli hledat souvislost s českým trestním právem dle zákona č. 40/2009 Sb., jinak řečeno, do této kategorie spadá velmi široké spektrum trestních skutkových podstat, které zahrnují některé skutkové podstaty trestných činů proti životu a zdraví - vražda, ubližení na zdraví apod. -, některé skutkové podstaty trestných činů proti svobodě a právům na ochranu osobnosti - loupež apod. -, některé skutkové podstaty trestných činů proti lidské důstojnosti v sexuální oblasti - znásilnění, sexuální nátlak apod. - a také některé skutkové podstaty trestných činů proti pořádku ve věcech veřejných - výtržnictví apod. - a společný znak naplnění těchto skutkových podstat je pak ve formě spáchání těchto činů, a to se zbraní, kterou je opět bodná nebo sečná zbraň v těchto případech) a v neposlední řadě (3) tzv. „accid attacks“" (neboli útoky vedené proti oběti za použití korozní, resp. leptavé nebo žíravé substance, která oběti po zasažení obličejové části způsobí trvalé poškození obličejových tkání a v mnohých prípadech zanechá vážné zdravotní následky, jako např. ztráta zraku apod.).

Po analýze dostupných statistik zůstává nesporným faktem, že v posledních 4 letech došlo v oblasti kriminality v Londýně 
$\mathrm{k}$ extrémnímu nárůstu kriminality. $\mathrm{V}$ rámci této studie se omezíme na výše zmíněné formy této trestné činnosti s ohledem na nárůst kriminality. $V$ extrémních prípadech Ize hovořit až o nárůstu o 1,671 \% mezi dolním minimem a horním maximem ${ }^{21}$, např. u "moped crimes". U prípadu tzv. "accid attacks“ se naopak setkáváme s poměrně novým způsobem útoků.

V první řadě připomeňme, že Velká Británie je oproti např. České republice, která je pouhou tranzitní zemí, destinací cílovou, a i když "net“ migrace neboli čistá migrace ve Velké Británii částečně oslabila $v$ posledních letech ${ }^{22}$ a např. $v \mathrm{r}$. 2018 poklesla na cca 258000 z 332000 v r. 2015, jedná se stále o poměrně zásadní číslo, které nám vystoupá na zhruba 3300000 v průběhu jednoho desetiletí, což není tak dlouhá doba. Zde hovoříme o populaci srovnatelné s počtem obyvatel Moravy, což je zhruba jako třetina obyvatel České republiky, zatímco $v$ potaz nebyla brána fertilita legálně usazeného migrujícího obyvatelstva, počty nelegálně se zdržujicího obyvatelstva a ani poměr územního rozptylu této migrující masy, která není rovnoměrně situována po celém území Anglie, Skotska a Walsu, nýbrž dochází ke kumulaci - homogenizaci těchto etnik $v$ určitých oblastech, zejm. velkých metropolitních zónách, kdy přikladem je Londýn nebo Manchester, kde sledujeme systematické navyšování etnicky homogenních populaci v určitých městských částech.

\footnotetext{
${ }^{21}$ MCCARTHY, Niall. Moped crime is soaring in London. Statista [online]. 2018 [cit. 2019-09-16]. Dostupné z: https://www.statista.com/chart/14564/moped-crime-is -soaring-in-london/

${ }^{22}$ Net Migration Statistics. Migration watch UK [online]. 2019 [cit. 2019-09-16]. Dostupné z: https://www.migrationwatchuk.org/statistics-net-migration-statistics
} 


\section{1 „Moped crimes“}

Nevyvratitelný důkaz v podobě statistiky, která by přímo spojovala masovou migraci s nárazovým nárůstem této kriminální činnosti, neexistuje. Pro nás je ale zejména důležité hledání možné korelace mezi fenoménem masové migrace, která se může do jisté míry promítat v takovéto nárazové vině kriminality. Z předchozích statistik je patrné, že vlna masové migrace kulminovala v Evropě v r. 2015 a totéž platí i pro Velkou Británii, kde je možné pozorovat cca 300 \% nárůst tohoto typu kriminální činnosti oproti předchozímu roku a tento trend pokračuje i v následujícím roce 2016 a kulminuje $v$ polovině $r$. 2017, kde se číselně pohybujeme $v$ relaci okolo 2500 útoků za měsíc v maximální horní hranici, což nám ve výsledném součtu poskytne číslo okolo 23000 útoků (cca 430-440 těchto útokủ za týden) tohoto typu ${ }^{23}$. Paralelní korelace, která poukazuje na exponenciální růst této kriminality ve stejných časových úsecích, ve kterých kulminovalo migrační působení ve Velké Británii, je nesporné. Sekundární paralelu můžeme i spatřovat $v$ mírném nynějším poklesu tohoto typu kriminality, který mírně koreluje s nižšími čísly přilivu migrujícího obyvatelstva, což ale nemusí být nutně jediným důvodem poklesu ${ }^{24}$, nebot' je nutné uvážit i roli bezpečnostních složek a jejich efektivitu a metodiku boje s tímto typem kriminality.

\footnotetext{
${ }^{23}$ CLARK, Daniel. Offences committed by suspects riding a moped or motorcycle at the time of offence in London from 2013 to 2017. Statista [online]. 2019 [cit. 2019-09-16]. Dostupné z: https://www.statista.com/statistics/867970/moped-crime-in-london/ ${ }^{24}$ Is moped crime rising in London? Fullfact.org [online]. 2018 [cit. 2019-09-16]. Dostupné z: https://fullfact.org/crime/moped-crime-rising-london/
} 


\section{2 „Knife crimes“}

Další rovinou, kam se promítá nárůst trestné činnosti, je oblast skutků spáchaných za použití bodné nebo sečné zbraně. I zde statistiky ukazuji konzistentní nárůst v posledních 4 letech a jedná se o zhruba $52 \%$ nárůst ${ }^{25}$. Na rozdíl od tzv. "moped crimes“ se nejedná o stavy zcela neobvyklé ${ }^{26}$.

Obdobná čísla nalezneme z období let 2010-2011. Zde se také velmi razantně reflektuji změny policejní metodiky boje se zločinem, jako např. razantní úpadek namátkových prohlídek, tzv. „stop and search“27, ale i jiné faktory, jakými mohou být zvýšená kriminalita $v$ prostředí organizovaných skupin a násilná činnost gangů, tzv. "gang violence“. V této rovině vystupuje do popředí fenomén tzv. "black on black crime“, kde je možné souhrnně konstatovat, že v počtu zadržených, zatčených, obžalovaných, odsouzených a uvězněných osob jsou \% nejvíce zastoupeny osoby různých barev pleti, tedy různých etnických minoritních (mějme na paměti, že tyto minority tvořily v r. 2011 pouhých 12,83 \% celkového počtu obyvatel Velké Británie) skupin ${ }^{28}$, které pocházejí z afrických a asijských regionů. Zajímavé je povšimnout si i toho, jak jsou tato etnika zastoupena v oblasti obětí trestné činnosti, a zde

\footnotetext{
${ }^{25}$ Knife crime in London. Office for national statistic [online]. 2019 [cit. 2019-09-26]. Dostupné z: https://www.ons.gov.uk/aboutus/transparencyandgovernance/freedomof informationfoi/knifecrimeinlondon

${ }^{26}$ CLARK, Daniel. Number of knife crimes recorded in London from 2010/11 to 2018/19 (in 1,000s). Statista [online]. 2019 [cit. 2019-09-16]. Dostupné z: https://www.statista. com/statistics/864736/knife-crime-in-london/

${ }^{27}$ SHAW, Danny. Ten charts on the rise of knife crime in England and Wales. BBC News [online]. 2019 [cit. 2019-09-17]. Dostupné z: https://www.bbc.com/news/uk-42749089 ${ }^{28}$ National Statistics: Race and the criminal justice system 2016. GOV.UK [online]. 2017 [cit. 2019-09-17]. Dostupné z: https://www.gov.uk/government/statistics/race-and-the -criminal-justice-system-2016
} 
také zaujímaji většinové \% postavení, a to zhruba v poměru 3,6 : 19,1 v porovnání s původním obyvatelstvem. $V$ oblasti odsuzujících rozsudků je tento poměr původního bílého britského obyvatelstva a etnických skupin $4: 27$ za rok 2016. $S$ ohledem na obsazenost věznic je poměrné zastoupení 15 : 164 v neprospěch etnických skupin, kde jediná etnická skupina, která je zastoupena menším dílem ve vězeňské populaci, je čínská menšina, a to podílem $13: 15$ vůči původnímu obyvatelstvu ${ }^{29}$. Posledním statistickým vstupem $v$ této oblasti je fakt, že Londýn poprvé v historii překonal New York v počtu vražd. Stalo se tak v únoru a březnu roku 2018. I když přesnou přičinu tohoto nárůstu nejsme schopni odhadnout, nebylo by zcela nevhodné akceptovat úvahu o možné korelaci nárůstu početního zastoupení etnických skupin a nárůstu trestné činnosti, nebot jak ukazuji statistiky britského ministerstva spravedlnosti, etnické menšiny zcela nesporně dominuji v zastoupení ve všech fázích trestního i vykonávacího řizení, resp. v obsazenosti vězeňských zařizení. Ve statistické perspektivě za rok 2017 se New York podržel s indexem 3,4 na 100000 obyvatel před Londýnem, který dosáhl hranice 1,2 - i přes tento značný rozdíl Londýn zaznamenal v prvních 3 měsících r. 2018 nárazový nárůst $v$ počtu vražd a za ledenbřezen r. 2018 se s počtem 45 vražd velice přibližil New Yorku, který za tyto 3 měsíce zaznamenal 57 vražd s tím, že v únoru a březnu Londýn fakticky New York předstihl. Závěrem tedy Ize poznamenat, že nejenže konzistentně stoupá počet útoků spáchaných bodnou nebo sečnou zbraní, ale také stoupá konzistentně počet vražd, a to od r. 2015, kdy kulminovala migrační vlna. Hodnoty v oblasti trestných činů vražd zatím nedosahuji takových hodnot jako v r. 2003, nicméně Velká

${ }^{29}$ Tamtéž. 
Británie opět překonala hranici, která byla v posledních 51 letech překročena pouze desetkrát ${ }^{30}$. Korelaci tedy můžeme spatřovat mezi statistikou poměru např. černošské etnické menšiny $v$ Londýně, kterou tvoří zhruba $13 \%$, a jejím procentuálním zastoupením $v$ oblasti podezřelých z trestného činu vraždy, které tvoři 48 \%. Zde ještě dodejme, že poměr zatčených ${ }^{31}$ této menšiny je 35 : 11 (vưči bělošské většině).

Díky dostupným statistikám je možné provést detailní komparativní studii. Je vždy nutné mít na paměti, že etnické minoritní skupiny budou početněji méně zastoupené v řadách pachatelů trestné činnosti, nebot z logiky věci vyplývá, že se jedná o minority - menšiny - a jejich celkové počty ani zdaleka nedosahuji početní hranice původního obyvatelstva, ale důležité je zmínit, že pro nás je klíčový poměr participace přislušníků menšin na trestné činnosti a tento poměrný koeficient zohledňuje celkové populační počty, resp. poměrný koeficient zastoupení etnické minority na kriminální činnosti počítáme z jiného základu a tím získáme přesnější souvislosti.

Tak tedy v roce 2010/2011 (rok, kdy proběhl velký cenzus ve Velké Británii - snažíme se vyhnout různým datovým predikcím, kde by mohlo dojít k různým nepřesnostem) bylo zatčeno 1353740 osob a z toho cca 259000 (konkrétně 258 622) zatčených osob bylo přislušníky etnických menšinových skupin kromě menšiny čínské a 1075562 zatčených bylo přislušníků

\footnotetext{
${ }^{30}$ ELKIN, Meghan. Homicide in England and Wales: year ending March 2018. Office for National Statistics [online]. 2019 [cit. 2019-09-17]. Dostupné z: https://www.ons. gov.uk/peoplepopulationandcommunity/crimeandjustice/articles/homicideineng landandwales/yearendingmarch2018

${ }^{31}$ Arrests. GOV.UK [online]. 2019 [cit. 2019-09-17]. Dostupné z: https://www.ethnicity-facts -figures.service.gov.uk/crime-justice-and-the-law/policing/number-of-arrests/latest
} 
bělošské většiny. Tato čísla jsou ale do jisté míry zavádějící, nebot' je musíme vykládat v souvislosti s celkovými počty všech přislušníků daných etnických menšin či většin, nebot populace Velké Británie není tvořena cca 27 miliony původního obyvatelstva a cca 27 miliony příslušníků BAME ${ }^{32}$, tzn., že základ pro výpočet našeho poměrného koeficientu bude číslo 55010359 pro výpočet koeficientu pro původní bělošské obyvatelstvo a základ pro výpočet koeficientu pro BAME bude 8108 626. Bělošská populace čítala 55010359 a došlo k 1075562 zatčením oproti BAME populaci, která čítala 8108626 a kde došlo ke 258622 zatčením. Finální poměrný koeficient je tedy $1,96 \%$ u bělošského obyvatelstva a 3,19 \% u populace BAME. Pro úplnost uvedeme, že z černošské minority bylo zatčeno 113085 z 1904684 osob (což je základ pro výpočet našeho \% poměrného koeficientu), což tvoři 5,94 \%. Zde docházíme k zajímavému zjištění, že poměr zatčených mezi bělošskou většinou a černošskou menšinou je po velmi hrubém zaokrouhlení v poměru $2: 6$, což je rovno poměru $1: 3$, tedy, jinými slovy, na 1 osobu bělošské většiny, která je umístěna do vězeňského systému, jsou zde ve stejném časovém období umístěny 3 osoby černošské menšiny. Na toto navazuje i statistika z r. 2018, která ř́ká: „Black people were over 3 times as likely to be arrested as White people - there were 35 arrests for every 1000 Black people, and 11 arrests for every 1000 White people. “33 Tato vládní

\footnotetext{
${ }^{32}$ BAME. Cambridge Dictionary [online]. (C2019 [cit. 2019-09-17]. Dostupné z: https:// dictionary.cambridge.org/dictionary/english/bame

${ }^{33}$ Arrests. GOV.UK [online]. 2019 [cit. 2019-09-17]. Dostupné z: https://www.ethnicity-facts -figures.service.gov.uk/crime-justice-and-the-law/policing/number-of-arrests/latest Populační data získána z webového portálu ONS - pro rok 2001. Ons.gov.uk [online]. 2019 [cit. 2019-09-17]. Dostupné z: http://www.ons.gov.uk/ons/rel/census/census2001-key-statistics/local-authorities-in-england-and-wales/local-authorities-ks06-ethnic-group.xls
} 
statistika také hovoří o poměru zatčení $1: 3$, což znamená, že zde panuje naprosto identický trend za posledních 8 let $\checkmark$ počtu kriminality páchané přislušníky etnických menšin.

Závěrem nutno dodat, že v oblasti zatčení došlo k 8 \% poklesu v r. 2017/2018 oproti roku předcházejícímu, mějme na paměti ale aspekt kriminální latence, která je také faktorem.

\section{3 „Accid attacks“}

Posledním příkladem, který budeme analyzovat, budou „kyselinové útoky“, kterých také v posledních letech přibývá, zejm. v Londýně. Hlavním korelačním kritériem v této oblasti bude fakt, že tato forma provedení útoku není obvyklá na evropském kontinentě. Oblasti, kde se tento kriminologický fenomén vyskytuje primárně, bychom zařadili mezi oblasti Blízkého - Dálného východu a některé regiony afrického kontinentu. $V$ tomto ohledu je také možné vysledovat určitou geograficko-historickou souvislost s výskytem této formy krutého a mrzačicího „trestu“, nikoliv v typickém významu

Analysis of Ethnicity in the 2001 Census - Summary Report. Gov.scot [online]. 2004 [cit. 2019-09-17]. Dostupné z: gov.scot/publications/analysis-ethnicity-2001-census -summary-report/pages/2/

Urban Area Summary Results For Local Authorities. Gov.scot [online]. (2019 [cit. 2019-09-17]. Dostupné z: http://www.ons.gov.uk/ons/rel/census/census-2001-keystatistics/urban-area-summary-results-for-local-authorities/urban-area-summaryresults-for-local-authorities-ks06--ethnic-group.xIs

Ethnic Group: KSO6 (statistical geographies). Northern Ireland Statistics and Research Agency [online]. @2019 [cit. 2019-09-17]. Dostupné z: http://www.ninis2.nisra.gov.uk/ Download/Census \%202001_Excel/2001/KS06 \%20\%20(st).xls

2011 Census: Ethnic group1, local authorities in the United Kingdom. Office for National Statistics [online]. (C2019 [cit. 2019-09-17]. Dostupné z: http://www.ons. gov.uk/ons/rel/census/2011-census/key-statistics-and-quick-statistics-for-localauthorities-in-the-united-kingdom---part-1/rft-ks201uk.xls 
pojmu trest, že by se jednalo o prvek soustavy trestů ukládaných veřejnou mocí, nýbrž jako prostředek retribučního projevu vůči osobě, zejm. ženám ( $v$ Londýně 80 \% obětí jsou ženy ${ }^{34}$ ), které vyvolaly u útočníka pohnutky ke spáchání takovéhoto činu. Velice silně se zde reflektují kulturní a historické zvyklosti, které jsou v těchto regionech založeny na striktní nerovnosti pohlaví a žena je vnímána pouze jako majetková hodnota. $V$ úvodu již bylo poukázáno na takovouto nerovnost ve sfére islámského práva. Na základě studií lze jako dominantni sféru manifestace tohoto kriminálního chování spojit s oblastí rodinných konfliktů a konfliktů v rámci vztahů, např. odmítnutí muže ženou ${ }^{35}$ apod. Paralelu Ize hledat i v hadísech (náboženské texty), které hovoři o tvrdých trestech jako veřejné bičování a kamenování žen, které se dopustily cizoložství, je zde tedy poměrně evidentní kulturně-náboženský vliv, který se manifestoval v podobě trestů nejen mrzačicích, ale také ponižujících (veřejný aspekt výkonu těchto trestů), tudiž je možné konstatovat, že cílem je jakési „zvrácené“ označení ženy - zasažení obličejové části tak, aby po zbytek života čelila studu a ponižení. $V$ první rovině zmiňme, že tato forma brutálního mrzačení je na vzestupu, a to od r. 2014. Webový portál A.S.T.i uvádí $90 \%$ nárůst těchto útoků v posledních 10 letech ve Velké Británii s tím, že pravděpodobně $60 \%$ těchto útoků není hlášeno a $z$ těch, co jsou nahlášeny, jen necelých $20 \%$ vyústí v trestní stíhání. Na základě údajů, které poskytla londýnská metropolitní policie, v r. 2014

\footnotetext{
${ }^{34}$ A WORLDWIDE PROBLEM. A.S.T.i [online]. (C2018 [cit. 2019-09-17]. Dostupné z: http://asti.org.uk/a-worldwide-problem.html

${ }^{35}$ Acid Violence in Uganda: A Situational Analysis. Wayback Machine [online]. 2011 [cit. 2019-09-17]. Dostupné z: https://web.archive.org/web/20130617010909/http:// www.acidviolence.org/uploads/files/Uganda_ASFU_Situational_Analysis_Report_ FINAL_Nov2011_1.pdf
} 
došlo k 166 incidentům, v r. 2015 došlo k 261 incidentům, v r. 2016 došlo k 455 incidentům a v prvních 4 měsících r. 2017 došlo k 113 incidentům ${ }^{36}$. Druhou rovinu představuje fakt, že na seznamu A.S.T.i zemí, které jsou reprezentovány nejvyšším počtem těchto útoků, jsou Indie, Pákistán a Bangladéš a nově tedy Velká Británie. Dalším faktem je, že na základě „BRIEFING PAPER Number CBP 8041, 17 December 2017“ připraveného pro Dolní sněmovnu britského parlamentu došlo v r. 2017 k výskytu těchto útoků primárně v londýnských městských částech Newham (149), Barking a Dagenham (58), Tower Hamlets (42), Redbridge (27) a Havering (25). $\checkmark$ neposlední řadě uved'me fakt, že zmiňované londýnské distrikty představuji etnicky nejdiverzifikovanějši městské části, kde jsou velmi silně zastoupené etnické menšiny Indů, Pákistánců a Bangladéšanů, jako např. Newham dominující této statistice s nejnižším \% zastoupením bělošského obyvatelstva, které se již v této městské části stalo menšinou s cca 29 \% zastoupením, zatímco Indie, Pákistán a Bangladéš jsou zastoupeny cca $36 \%$.

\footnotetext{
${ }^{36}$ Information Rights Unit - Acid attacks in the London area from January 2014 to April 2017. Metropolitan Police [online]. @2019 [cit. 2019-09-17]. Dostupné z: https:// maps.met.police.uk/SysSiteAssets/foi-media/metropolitan-police/disclosure_2017/ july_2017/information-rights-unit---acid-attacks-in-the-london-area-from-january2014-to-april-2017
} 


\section{Reakce států na danou situaci a návrhy jejího řešení}

V této kapitole částečně navážeme na kapitolu předchozí (1.3 Rozrušování hodnotového rámce), nebot to, jakým způsobem a za použití jakých metod státy přistupují k výzvám, které provázejí fenomén masové migrace, může bud' přispět k ochraně hodnotového rámce západních liberálně-demokratických zemí euroregionu, anebo může dojít k narušení a prolomení této sféry, a to zejm. v podobě zásahů do ústavně zaručených základních práv a svobod, a to jak ze strany orgánů veřejné moci, tak také konáním omisivním (zásahy do sféry nedotknutelnosti osoby a podrobení krutému, nelidskému a ponižujícímu zacházení - při aplikaci obyčejových právních norem na základě principu personality práva, zde by $v$ úvahu připadal výkon vlastního soudnictví v rámci "ghettoizovaných“ komunit a vědomé rozhodnutí orgánu místní správy zdržet se jakéhokoliv zásahu na základě odklonu od principu rovnosti před zákonem a príklonu k principu exempce a dvojkolejného soudnictví ve snaze zaručit straně sporu, která je etnickou menšinou, soudce, který je také příslušníkem etnické menšiny; omezení vlastnického práva - orgán veřejné moci prikáže odstranění náboženských - křestanských - symbolů s cílem vyhnout se eskalaci náboženského polarismu; prolomení zásady nedotknutelnosti obydlí - pokud by došlo k nucené relokaci původniho obyvatelstva s cilem etnicky homogenizovat městskou část nově příchozího obyvatelstva; zásahy se mohou vyskytnout i ve sféře omezení svobody náboženského vyznání, resp. projevu tohoto náboženství - různé formy odstraňování křestanských symbolů a ikon s cílem neeskalovat náboženskou netoleranci aj.). 


\subsection{Vybrané příklady přístupu $k$ fenoménu masové migrace}

Z podstaty věci není možné vyjmenovat komplexně všechny formy realizace státní ingerence $v$ oblasti masové migrace $s$ cílem dostat tento fenomén aspoň částečně pod kontrolu. Do popředí nicméně vystupuji tři formy metodiky řešení - postojů $\mathrm{k}$ dané situaci:

a) vyhýbavý přístup - ten se může manifestovat např. v podobě odmítání aktualizace statistik, které se týkají negativních vlivů migrace, ale může mít i jiné podoby a formy, tento postoj částečně uznává existenci masové migrace, ale hlavním cílem je vyhnout se jakékoliv konfrontaci; ve své krajní podobě může tento postoj vést až $\mathrm{k}$ podřizení se východním tradicím (zde můžeme uvést např. Švédsko),

b) přístup zprostředkovaně konfrontační - zde již hovoříme o plném uznání fenoménu migrace a jeho možné hrozby pro hodnotový rámec euroregionu, ale ve své podstatě je tento přistup typický pro hledání neprímého, resp. zprostředkovaného způsobu řešení, které se obvykle manifestuje ve formě zákazů a omezení - demonstrujme tuto situaci na jednoduchém příkladu z praxe, o kterém jsme hovořili v minulé kapitole: v Londýně exponenciálně vzrostl počet tzv. „acid attacks“ a 26. března 2015 byl novelizován Poisons Act 1972 s cílem zpřísnit kontrolu látek, které mohou způsobit leptavá a další vážná poranění; všeobecným přikladem tohoto přístupu $\mathrm{k}$ řešení problematiky kriminality by mohly být různé vyhlášky a zákony zakazující 
nosit nebo vlastnit zbraň (střelnou, bodnou) s cílem snižit počet vražd apod. Jinak řečeno, tento přistup neřeší samotné jádro problému, nýbrž hledá různá kvaziřešení s cílem mitigovat negativní projevy daného fenoménu (přikladem může být např. Velká Británie, platí zákaz nošení nože s čepelí delši jak $7,62 \mathrm{~cm}$ pod trestem odnětí svobody s horní hranicí 4 let na základě Offensive Weapons Act 2019 PART 4 (7) (3) b),

c) přístup konfrontační - tato forma reakce na danou problematiku je prímá a bezprostřední, nebot nejenže je zde plně akceptována existence fenoménu masové migrace, ale na tento jev je $v$ této fázi nahliženo již jako na něco negativního anebo něco, co s sebou přináší jistou míru ohrožení, a je proto nutná okamžitá reakce, obvykle ve formě posílení vnitřní bezpečnosti - formy projevu tohoto prístupu mohou představovat např. zvyšování počtu přislušníků bezpečnostních složek, zakládání speciálních vyšetřovacích útvarů, které se velmi nevybíravě zaměřuji na oblasti se zvýšenou kriminalitou, aj. (zde můžeme uvést např. Německo ${ }^{37}$, ale paradoxně i Velkou Británii, nebot nejenže není možné státy diverzifikovat do těchto 3 skupin zcela jednoznačně, ale $v$ průběhu času docházi k plynulému prechodu mezi jednotlivými stupni porozumění dané problematice a $v$ návaznosti na to $k$ opatřením, která jsou prijata - $v$ prípadě Velké Británie se jedná o rozhodnutí navýšit stavy příslušníků policie o 20000 v následujících třech letech, což potvrdil

${ }^{37}$ CDU will Pakt für einen starken Rechtsstaat. Christlich Demokratische Union Deutschlands [online]. (C2019 [cit. 2019-09-17]. Dostupné z: https://www.cdu.de/artikel/ cdu-will-pakt-fuer-einen-starken-rechtsstaat 
britský premiér Boris Johnson 26. června 2019 ve svém prohlášenïis).

\subsection{Aplikace právních instrumentů - vybrané příklady z oblasti mezinárodní i z oblasti České republiky}

Nad rámec 3 distinktivních prístupů, které jsme profilovali výše, je také možné dělení této problematiky na základě vertikální sféry vlivů právních instrumentů, a to na:

a) Úroveň mezinárodního rámce - ve sféře mezinárodních bilaterálních a multilaterálních smluv, paktů a jiných právních pramenů existuje velmi objemná právní matérie, která je zaměřena na tuto problematiku. Pro účely naší studie, která hledá souvislosti mezi působením fenoménu migrace a různými sférami negativního dopadu, jaké tento fenomén může přinášet, by bylo ideální zaměrit se na dva prameny, a to jednak na newyorskou deklaraci, tzv. New York Declaration for Refugees and Migrants z r. 2016, a jednak Dohodu o uprchlících, tzv. Global Compact on Refugees z r. 2018.

První ze jmenovaných instrumentů vznikl na půdě OSN v rámci summitu Valného shromáždění, který se konal 19. zárí 2016, a tato deklarace byla jednohlasně príijata prostřednictvím Rezoluce 71/1. Cílem tohoto dokumentu je zlepšení prístupu mezinárodní

${ }^{38}$ Press release: Prime Minister launches police recruitment drive. GOV.UK [online]. 2019 [cit. 2019-09-17]. Dostupné z: https://www.gov.uk/government/news/prime -minister-launches-police-recruitment-drive 
komunity k masové migraci ${ }^{39}$ - pro nás je tento dokument významný zejm. z pohledu toho, že představuje významný zlomový moment v podpoře a přechodu ke globální solidaritě a ochraně uprchlíků, a to v podobě finančních podpor hostitelským zemím, podpoře uprchlickým komunitám apod. - pozitivní aspekty mohou být spatřovány ve snaze pracovat s fenoménem migrace na globální úrovni, nicméně určité riziko může představovat diskutabilní a vágní rétorika, která hovoři o znovuosídlování a snaze nalezení vhodných míst k usazení všech uprchlíků, kterým UNHCR (The UN Refugee Agency) tento status priděli ${ }^{40}$.

Druhým dokumentem je tzv. Global Compact on Migration z r. 2018 (též známý pod názvem „Global Compact for Safe, Orderly and Regular Migration“), který je úzce spojen s předchozí deklarací, která iniciovala vznik tohoto sekundárního dokumentu. Navzdory tomu, že se nejedná o dokument právně závazný, v prípadě své adopce jednotlivými státy by představoval silný mechanismus státní odezvy na migrační vlny většího rozsahu - tento dokument je postaven na 23 zásadách, které spojuje jednotný postoj $\mathrm{k}$ osobě uprchlíka jako k oběti, jsou zde velmi patrné snahy o dosažení maximální úrovně integrace do společnosti cílové země, a to patrně i za cenu možného ohrožení vnitřní bezpečnosti ve státě. Není zde pochyb o tom, že osoba, která je přemístěna do cílového státu bez

\footnotetext{
${ }^{39}$ The New York Declaration for Refugees and Migrants Answers to Frequently Asked Questions. UNHCR [online]. 2019 [cit. 2019-09-17]. Dostupné z: https://www.unhcr. org/584689257.pdf

${ }^{40}$ New York Declaration. Refugees and Migrants [online]. (C2019 [cit. 2019-09-17]. Dostupné z: https://refugeesmigrants.un.org/declaration
} 
jakýchkoliv finančních prostředků, neovládá místní jazyk a nedosáhla žádného stupně vzdělání, je osobou zranitelnou, nicméně, jak ukazuji četné vládní statistiky, fakt, že osoba spadá do kategorie zranitelných osob, ještě neznamená, že tato osoba se sama nedopustí trestné činnosti, a to paradoxně mnohdy z důvodů, které jsou nedílně spjaty s tímto zranitelným postavením (např. absence finančních prostředků může vyústit v opakující se sérii krádeží či loupeží apod.). Tzn., že dokumenty tohoto typu představuji riziko ve formě zastírání pravé podstaty problematiky, nebot’ pokud hovoříme o masové migraci, je nutné analyzovat jak aspekty pozitivní, tak aspekty negativní - konkrétním příkladem ohrožení vnitřní bezpečnosti pak může být např. „Establish mechanisms to prevent, detect and respond to racial, ethnic and religious profiling of migrants by public authorities, as well as systematic instances of intolerance, xenophobia, racism and all other multiple and intersecting forms of discrimination, in partnership with national human rights institutions, including by tracking and publishing trend analyses, and ensuring access to effective complaint and redress mechanisms"41 (zde by se pak konkrétně jednalo o zabránění etnické a náboženské profilace migrujícího obyvatelstva a také zabránění zveřejňování trendových analýz, které by mohly, jako např. tato studie, poukázat na možná rizika spojená $s$ fenoménem globální migrace, přičemž bizarnost

${ }^{41}$ Intergovernmental Conference to Adopt the Global Compact for Safe: Orderly and Regular Migration. United Nations [online]. @2019, s. 23 [cit. 2019-09-17]. Dostupné z: https://undocs.org/en/A/CONF.231/3 
tohoto řešeni spočívá $v$ tom, že problém budeme řešit tím, že zakážeme se o něm zmiňovat, a to na základě podpory principů solidarity a tolerance, což nelze spatřovat jako zcela ideální trend, nebot to jsou právě rozsáhlé kriminologické statistiky, které dovoluji volbu efektivnějších metod při zvládání rozličných výzev).

Pokud hovořime o mezinárodních dokumentech (zejm. vznikajícich na půdě OSN - např. výše zmíněný GCM), je zajímavé si i povšimnout jisté změny právni terminologie, kde se již hovoři o „regular migrants“ a „irregular migrants" a tyto pojmy do jisté míry nahrazují pojmy legální a nelegální migrace. Zde by se tedy dokonce dalo spekulovat o snaze odstranit jakékoliv negativní konotace ve spojitosti s fenoménem migrace za účelem, aby migrace nebyla vnímána jako cosi nelegálního - protiprávního -, což samo o sobě obsahuje určitý stupeň podvědomé negativity a může být automaticky vykládáno jako něco špatného, zatímco pojem „irregular" sice také může být přeložen jako protizákonný, obvykle ho však překládáme jako nepravidelný či nerovnoměrný.

b) Úroveň evropského rámce - $v$ této sféře se bude jednat primárně o projevy řizení a kontroly legálních migračních toků (např. navyšování počtu specializovaných a kvalifikovaných pracovníků nebo zavádění různých koordinačních projektů s cilem sjednotit a vytvořit jednotný rámec postupů a pravidel při zpracovávání žádostí o azyl a procesu řizeného přesidlovánî), prípadně se může jednat o koordinaci navrácení nelegálních migrantů, tzv. repatriaci, nebo se může jednat o jakékoliv dalši projevy spadajíci do kategorie společné 
azylové politiky, která svůj právní základ nachází v čl. 67 a 78 SFEU a také čl. 18 Listiny základních práv EU.

c) Úroveň ústavního rámce individuálních států - $z$ pohledu českého ústavního práva je evidentní, že český ústavodárce do značné míry prioritizoval svrchovanost, jednotnost a demokratičnost, resp. demokratický charakter státu a zároveň ochranu a obranu těchto hodnot, jak vyplývá z Ústavy České republiky a také z ústavního zákona o bezpečnosti České republiky - s ohledem na ústavní maximu v čl. 9 odst. 2 Ústavy České republiky bychom mohli konstatovat, že tato klauzule věčnosti může sehrát i úlohu jakési „rezistentní klauzule“, a to právě při ochraně materiálního ohniska ústavnosti v případě útoku na hodnoty demokratického právního státu ( $v$ tomto ohledu bude do popredí vystupovat role Ústavního soudu České republiky, nebot je to právě on, kdo vykládá pojem podstatných náležitostí demokratického právního státu vzhledem $k$ záměrné absenci definice tohoto pojmu v Ústavě České republiky). Význam materiálního ohniska ústavnosti by se stal tedy klíčovým např. v případě existence právních instrumentů reagujících na migrační fenomén, jejichž aplikací by docházelo k odstraňování demokratického charakteru státu.

d) Úroveň zákonného (případně podzákonného) rámce individuálních států - pokud hovoříme o zákonném rámci a jeho instrumentech, které by se dotýkaly problematiky migrace v České republice, můžeme zmínit novelu zákona o $\mathrm{BIS}^{42}$, která byla vládou předložena

${ }^{42}$ Vláda navrhla významné posilení bezpečnosti České republiky. Bezpečnostní informační s/užba [online]. 2018 [cit. 2019-09-17]. Dostupné z: https://www.bis.cz/aktuality/ vlada-navrhla-vyznamne-posileni-bezpecnosti-ceske-republiky-6ff3db23.html 
v r. 2018 a sledovala posilnění v oblasti vnitřní bezpečnosti např. pomocí sledování finančních toků peněz nebo vytvořením moderní softwarové databáze identit, což by přispělo $k$ větší flexibilitě, pružnosti a efektivitě při plnění zákonem stanovených funkcí; v rovině zákonné úpravy hraje klíčovou roli i zákon č. 40/2009 Sb., trestní zákoník, který pokrývá základní skutkové podstaty trestné činnosti spojené s nelegální migrací, např. § 339 Násilné překročení státní hranice, § 340 Organizování a umožnění nedovoleného překročení státní hranice, § 341 Napomáhání $k$ neoprávněnému pobytu na území republiky aj. Ve sféře podzákonné hraje nezastupitelnou úlohu Ministerstvo vnitra České republiky (které je de facto hlavním orgánem veřejné moci v oblasti azylu a migrace - $v$ rámci tohoto ministerstva je problematika migrace delegována na vnitřní odbor azylové a migrační politiky, tzv. OAMP), a to jednak s ohledem na tvorbu podzákonných normativních aktů, ale zejm. s ohledem na monitoring situace migrace a publikací souhrnných zpráv o migraci za jednotlivá čtvrtletí roku.

\section{Závěr - je možné tuto situaci podřadit pod pojem tzv. nestandardních bezpečnostních situací ve státě?}

Závěrem by tedy bylo adekvátní odpovědět na otázku, zdali můžeme fenomén masové migrace a některé jevy, které jsou $s$ tímto fenoménem neoddělitelně spjaty, označit za tzv. nestandardní bezpečnostní situaci ve státě a následně zaujmout prognostické stanovisko pro futuro. 
Na základě všech předložených statistických údajů je nutné považovat za prokázanou existenci samotné masové migrace, která se odehrává v rádech několika set tisíců osob za rok (záleží, jaký stát takto analyticky zkoumáme). Dále je nutné považovat za prokázaný fakt, že omezení, a to i velice radikální, migrace nelegální nemusí zcela nutně znamenat omezení či zastavení migrace legální. Dále je nutné označit za prokázaný fakt, že existuje propastný rozdíl mezi kulturním světem euroregionu a oblastmi, ze kterých do euroregionu proudi uprchlíci - migranti. Adekvátnosti zcela pozbývají pokusy o zhodnocení, jaké rozdíly jsou dobré a jaké špatné. To není podstatné, podstatné je, že tyto rozdíly existují a jejich samotná existence vytváři $v$ mnohých připadech integrační kolize, které $v$ dlouhodobějším měřítku velmi často vyústí v enklavizaci migrujícího obyvatelstva, kde operujeme s pojmy jako ghettoizace či neoapartheid, jinými slovy nedochází k plošnému rozptýlení migrujícího obyvatelstva, nýbrž $\mathrm{k}$ jeho kumulaci v destinačních zónách, kde v dalši etapě dochází k manifestaci tzv. „přečíslováni“, kde původní majoritní obyvatelstvo se postupem času stává skupinou minoritní a následně dochází $\mathrm{k}$ jakémusi pomysInému oddělení těchto enklavizovaných komunit z homogenní sféry územní celistvosti daného státu, jinými slovy, ad absurdum Ize v extrémních případech hovořit o vzniku jakýchsi „států ve státě“, přičemž vlivem tohoto působení dojde i k oslabení mocenského vlivu na dané území. Dále je možné považovat za prokázané, že ačkoliv můžeme vysledovat pozitivní aspekty dopadu migrace, existuji i roviny negativní a $v$ těchto rovinách pak můžeme hovořit o tzv. "rozrušování demokratických hodnot“. V samotném jádru studie byla pozornost věnována exponenciálnímu nárůstu kriminality v Londýně, ve Velké Británii, který časově 
bud' prímo korespondoval s obdobím, kdy kulminovala masová migrační vlna $v$ r. 2015, anebo přinejmenším s těmito časovými úseky koreloval. Za zcela jistě prokázané nelze považovat, že migranti, kteři se dostali na území Velké Británie v letech 2014-2016, byli přesně těmi osobami, které se této kriminální činnosti dopouštěly, nicméně určitou korelaci Ize vyvodit ze statistik britského ministerstva spravedlnosti, ze kterého vyplývá značný nepoměr zastoupení v řadách obžalovaných a odsouzených za trestnou činnost - z těchto statistik zcela nezpochybnitelně vyplývá fakt, že etnické menšiny jsou ve velkém nepoměru zastoupeny $v$ řadách osob podezřelých ze spáchání trestných činů a zejm. odsouzených. Druhým aspektem, který bychom mohli označit za korelační, je fakt, že $v$ etnicky velmi diverzifikovaných městských částech dochází ke spáchání trestné činnosti způsoby, které jsou typické pro domovské státy těchto menšin, např. kyselinové útoky apod.

Reakce jednotlivých států na tento fenomén jsou různé. Na základě uvedených a prostudovaných pramenů je ale opět možné nezpochybnitelně konstatovat, že některé přistupy řešení těchto migračních výzev mohou jak v krátkodobém, tak zejm. dlouhodobém měřitku představovat velice citelný zásah do sféry základních lidských práv a jak ze strany institucionálního systému mocenských autorit, tak ze strany nově príchozi masy obyvatelstva, která nebude sdílet ochotu uznávat konstrukt právně demokratického státu $v$ materiálním pojetí ve světle judikatury ústavních soudů evropských zemí.

S ohledem na prognostickou situaci si dovoluji odmitnout tvrzení, která operují s vágními formulacemi, že možný vývoj odhalí až zítřek, a dodávám, že s ohledem na dostupné 
statistiky různých vládních i nevládních institucí a orgánů zítřek nastal již včera. Pomocí statistických údajů jsme schopni teorii převádět do praxe a formulovat kvalifikované předpovědi možného budoucího vývoje.

Situace týkající se migrace v České republice je dlouhodobě stabilní a podléhá dohledu Ministerstva vnitra České republiky a tento modus operandi prostřednictvím průběžného monitoringu Ize hodnotit jen pozitivně a jako efektivní vynaložení finančních prostředků ze státniho rozpočtu. Ale i tak je možné z grafů a statistik vyvodit postupný a souvislý nárůst počtu cizinců pobývajících na území České republiky, jejichž počet k 31. prosinci 2018 tvořil 566 931, což bylo o $8 \%$ více než v r. 2017. Situace ve Velké Británii je do značné míry závažnějši. Klíčové roky pro naši studii byly roky, kdy byly prováděny cenzy, resp. sčíáni obyvatelstva, a to konkrétně roky 2001 a 2011. V tomto časovém úseku došlo k nárůstu bělošského obyvatelstva o cca $1,70 \%$, zatímco ve stejném časovém úseku došlo $\mathrm{k}$ nárůstu počtu některých etnických menšin o cca 65-70 \%.

Renaud Camus hovoři o fenoménu „Le Grand Remplacement" neboli "The Great Replacement", který bychom mohli překládat jako „velké nahrazeni“ či „velké přečíslováni“". Nejedná se o nějakou mediální dezinformaci, nýbrž zaujetí kvalifikovaného postoje ke statistickým faktům. Uvažme, že na zachování populační úrovně je třeba, aby daný národ nebo etnikum dosáhly fertility, která je rovna číslu 2,0, pokud nebereme v potaz náhlá úmrtí apod. $V$ Evropě se $v$ současné době drží na prvním místě v oblasti fertility Francie, která v r. 2017 dosáhla v průměru čísla 1,9. Pokud analyzujeme historická 
data $v$ širším kontextu, tak došlo v Evropě k propadu indexu fertility z 2,6 v r. 1960 na hranici 1,6 v r. 2015, což je propad o skoro $40 \%$ za 55 let. To se bude reflektovat i do poměru celkové světové populace, kdy v r. 1950 tvořila Evropa cca $15 \%$ světové populace, zatímco predikce hovoři o propadu na pouhých $5 \%$ v r. 2100. Dáme-li do souvislosti údaje o porodnosti a údaje o konzistentní fluktuaci migrace, není nereálné presumovat, že $v$ časovém úseku jedné generace se občané některých evropských zemí stanou minoritami ve svých vlastních zemích. To, jaký postoj k těmto faktům dané státy zaujmou, už bude záviset pouze na politicko-právních procesech daných zemí.

Na závěr bych dodal to, že největši riziko dopadu negativních aspektů fenoménu migrace spočivá ve velmi pliživém charakteru narušování demokratického rámce společnosti a také $v$ miŕe latence mezi sběrem statistických údajů a jejich publikací v dostupném médiu. $S$ ohledem na ochranu ústavnosti doc. JUDr. Monika Forejtová, Ph.D., také dodává, že „ústavní garance právniho státu mohou být ve světle neřiditelných společenských turbulenci velmi křehkou substancí, jež může při nesprávné kombinaci ingrediencí bolestně implodovat". Co také zůstává velmi křehkou substancí, je i prostor svobody, bezpečnosti a práva, který je vytvořen $k$ ochraně komplexního rámce demokratických hodnot a jehož pomysIná rovnováha může být velmi snadno vychýlena a opětovné hledání a nalezení této rovnováhy může být $v$ krajních prípadech až nemožné. Kličové tedy je, abychom zaujali vůči této problematice společný postoj a překonali bipolární roztřištěnost, odhlédli od politicky motivovaných postojů populismu a sjednotili se za společnou 
frontu obrany a ochrany liberálně-demokratického právního materiálního státu. Již mnoho lidí položilo vlastní život v boji za demokracii v procesu budování liberálně-demokratického státu s hodnotami a principy, jaké známe dnes, a s ohledem na sebeobětování těchto osob jim my jakožto soudobá společnost přinejmenším dlužíme to, že o těchto otázkách bude veden dialog, a to nejen dialog $v$ rámci akademické obce, ale i takový dialog, který může posléze expandovat i do podoby národních a nadnárodních bezpečnostních konferencí a summitů, a to i za cenu toho, že se takovýto dialog nebo prípadová studie dostanou do konfliktu s mezinárodními právními instrumenty, nebot některé $z$ těchto mezinárodních pramenů práva se vyznačuji bizarními charakteristikami s ohledem na intencionální originalismus, které zasahuji do ústavně zaručených svobod projevu, práva vyhledávat a šírit informace a svobody vědeckého bádání.

\section{POUŽITÉ PRAMENY}

\section{Tištěné zdroje}

FOREJTOVÁ, Monika. Právní stát ve světle evropských hodnot a ústavních garancí demokracie $v$ mezinárodní perspektivě. Plzeň: Západočeská univerzita v Plzni, 2018, s. 67. ISBN 978-80-261-0859-7.

\section{Internetové zdroje}

2011 Census: Ethnic group 1, local authorities in the United Kingdom. Office for National Statistics [online]. ()2019 
[cit. 2019-09-17]. Dostupné z: http://www.ons.gov.uk/ons/ $\mathrm{rel} / \mathrm{census/2011-census/key-statistics-and-quick-statistics-}$ for-local-authorities-in-the-united-kingdom---part-1/rft -ks201uk.xls

A WORLDWIDE PROBLEM. A.S.T.i [online]. (C2018 [cit. 201909-17]. Dostupné z: http://asti.org.uk/a-worldwide-problem. html

Acid Violence in Uganda: A Situational Analysis. Wayback Machine [online]. 2011 [cit. 2019-09-17]. Dostupné z: https:// web.archive.org/web/20130617010909/http://www. acidviolence.org/uploads/files/Uganda_ASFU_Situational _Analysis_Report_FINAL_Nov2011_1.pdf

Analysis of Ethnicity in the 2001 Census - Summary Report. Gov.scot [online]. 2004 [cit. 2019-09-17]. Dostupné z: gov.scot/publications/analysis-ethnicity-2001-census -summary-report/pages/2/

Arrests. GOV.UK [online]. 2019 [cit. 2019-09-17]. Dostupné z: https://www.ethnicity-facts-figures.service.gov.uk/crime -justice-and-the-law/policing/number-of-arrests/latest

BAME. Cambridge Dictionary [online]. (C2019 [cit. 2019-09-17]. Dostupné z: https://dictionary.cambridge.org/dictionary/ english/bame

BARRY, Sinead. Fertility rate drop will see EU population shrink $13 \%$ by year 2100 ; active graphic. Euronews. [online]. 2019 [cit. 2019-09-16]. Dostupné z: https://www.euro news.com/2019/06/18/watch-changes-in-eu-populations -over-the-past-70-years

Blackburn White Fright Divided Britain. Youtube.com: video [online]. 2018 [cit. 2019-09-16]. Dostupné z: https://www. youtube.com/watch?v=RUmiCS-gRQs 
CDU will Pakt für einen starken Rechtsstaat. Christlich Demokratische Union Deutschlands [online]. (C)2019 [cit. 2019-09-17]. Dostupné z: https://www.cdu.de/artikel/cdu -will-pakt-fuer-einen-starken-rechtsstaat

CLARK, Daniel. Number of knife crimes recorded in London from 2010/11 to 2018/19. Statista [online]. 2019 [cit. 201909-16]. Dostupné z: https://www.statista.com/statistics/ 864736/knife-crime-in-london/

CLARK, Daniel. Offences committed by suspects riding a moped or motorcycle at the time of offence in London from 2013 to 2017. Statista [online]. 2019 [cit. 2019-09-16]. Dostupné z: https://www.statista.com/statistics/867970/ moped-crime-in-london/

CSO statistical publication, 31 August 2018, 11am: Vital Statistics Quarter 1 2018. Cso.ie [online]. 2019 [cit. 201909-16]. Dostupné z: https://www.cso.ie/en/releasesand publications/ep/p-vs/vitalstatisticsfirstquarter2018/

Demography of the United Kingdom. Wikipedia.org: the free encyclopedia [online]. 2019 [cit. 2019-09-16]. Dostupné z: https://en.wikipedia.org/wiki/Demography_of_the_United _Kingdom

Demography. Wikipedia.org: the free encyclopedia [online]. 2019 [cit. 2019-09-16]. Dostupné z: https://en.wikipedia. org/wiki/Blackburn\#Demography

ELKIN, Meghan. Homicide in England and Wales: year ending March 2018. Office for National Statistics [online]. 2019 [cit. 2019-09-17]. Dostupné z: https://www.ons.gov.uk/ peoplepopulationandcommunity/crimeandjustice/articles/ homicideinenglandandwales/yearendingmarch2018

Ethnic Group: KSO6 (statistical geographies). Northern Ireland Statistics and Research Agency [online]. (C)2019 [cit. 
2019-09-17]. Dostupné z: http://www.ninis2.nisra.gov.uk/ Download/Census \%202001_Excel/2001/KS06 \%20 \%20 (st).xls

Fertility statistics. Eurostat: statistic explained [online]. 2019 [cit. 2019-09-16]. Dostupné z: https://ec.europa.eu/euro stat/statistics-explained/index.php/Fertility_statistics

FLATLEY, John. Crime in England and Wales: year ending Mar 2017: Crime against households and adults, also including data on crime experienced by children, and crimes against businesses and society. Office for national statistic [online]. 2017 [cit. 2019-09-16]. Dostupné z: https://www.ons.gov.uk/peoplepopulationandcommunity/ crimeandjustice/bulletins/crimeinenglandandwales/year endingmar2017\#toc

Infografika. Migrační toky: trasa přes východní, centrální a západní Středomoři. Evropská rada: Rada Evropské unie [online]. 2019 [cit. 2019-09-26]. Dostupné z: https:// www.consilium.europa.eu/cs/infographics/eastern-and -central-mediterranean-routes-09-2017/

Infografika. Migrační politika EU. Evropská rada: Rada Evropské unie [online]. 2019 [cit. 2019-09-16]. Dostupné z: https://www.consilium.europa.eu/cs/policies/migratory -pressures/

Information Rights Unit - Acid attacks in the London area from January 2014 to April 2017. Metropolitan Police [online]. (2019 [cit. 2019-09-17]. Dostupné z: https://maps. met.police.uk/SysSiteAssets/foi-media/metropolitan -police/disclosure_2017/july_2017/information-rightsunit---acid-attacks-in-the-london-area-from-january-2014 -to-april-2017 
Intergovernmental Conference to Adopt the Global Compact for Safe: Orderly and Regular Migration. United Nations [online]. @2019, s. 23 [cit. 2019-09-17]. Dostupné z: https:// undocs.org/en/A/CONF.231/3

Is moped crime rising in London? Fullfact.org [online]. 2018 [cit. 2019-09-16]. Dostupné z: https://fullfact.org/crime/ moped-crime-rising-london/

Jordan Peterson - on Islam. Youtube.com: video [online]. 2017 [cit. 2019-09-16]. Dostupné z: https://www.youtube. $\mathrm{com} / \mathrm{watch}$ ?v=5yjdl3a-eRw

Knife crime in London. Office for national statistic [online]. 2019 [cit. 2019-09-26]. Dostupné z: https://www.ons. gov.uk/aboutus/transparencyandgovernance/freedomof informationfoi/knifecrimeinlondon

Look Inside Britain's Moped Crime Gangs. Youtube.com: video [online]. 2019 [cit. 2019-09-16]. Dostupné z: https:// www.youtube.com/watch?v=LECDoOLkO2c

Lammy review: final report. Gov.uk [online]. 2017, s. 6 a 31 [cit. 2019-09-16]. Dostupné z: https://www.gov.uk/govern ment/publications/lammy-review-final-report

MCCARTHY, Niall. Moped crime is soaring in London. Statista [online]. 2018 [cit. 2019-09-16]. Dostupné z: https://www.statista.com/chart/14564/moped-crime -is-soaring-in-london/

MIGRACE. Ministerstvo vnitra České republiky [online]. (C2019 [cit. 2019-09-17]. Dostupné z: https://www.mvcr.cz/ migrace/

Migration Statistics Quarterly Report: November 2018. Office for national statistic [online]. 2018 [cit. 2019-09-16]. Dostupné z: https://www.ons.gov.uk/peoplepopulationand community/populationandmigration/internationalmigration/ 
bulletins/migrationstatisticsquarterlyreport/november 2018

Ministerstvo vnitra vydalo pravidelnou souhrnnou zprávu Ministerstva vnitra o migraci za II. čtvrtletí roku 2019. Ministerstvo vnitra České republiky [online]. (C)2019 [cit. 2019-09-17]. Dostupné z: https://www.mvcr.cz/migrace/ clanek/ministerstvo-vnitra-vydalo-pravidelnou-souhrnnou -zpravu-ministerstva-vnitra-o-migraci-za-ii-ctvrtleti-roku -2019.aspx

National Statistics: Race and the criminal justice system 2016. GOV.UK [online]. 2017 [cit. 2019-09-17]. Dostupné z: https://www.gov.uk/government/statistics/race-and-the -criminal-justice-system-2016

Net Migration Statistics. Migration watch UK [online]. 2019 [cit. 2019-09-16]. Dostupné z: https://www.migration watchuk.org/statistics-net-migration-statistics

New York Declaration. Refugees and Migrants [online]. (C2019 [cit. 2019-09-17]. Dostupné z: https://refugeesmigrants. un.org/declaration

Norway's call to remove crosses causes backlash. The local no [online]. [cit. 2019-09-16]. Dostupné z: https://www. thelocal.no/20151130/norway-remove-cross-refugees

Nová citační norma ČSN ISO 690:2011, bibliografické citace. Sites Google [online]. (C2019 [cit. 2019-09-16]. Dostupné z: https://sites.google.com/site/novaiso690/schema-a-priklady/ elektronick-zdroje

OBYVATELSTVO. Prírodovědecká fakulta Univerzity Karlovy [online]. Český statistický úřad, (C2001 [cit. 2019-09-16]. Dostupné z: https://web.natur.cuni.cz/ mak/gos/dem metodika/www.czso.cz/cz/cisla/0/02/020100/obyvatel.htm 
PAULY, Jan. Vyhláška děkana FPR č. 33D/ 2019, o státní závěrečné zkoušce - obhajoba diplomové nebo bakalářské práce. Fakulta právnická, Západočeská univerzita v Plzni [online]. (C2018 [cit. 2019-09-16]. Dostupné z: https://web. natur.cuni.cz/ mak/gos/demmetodika/www.czso.cz/cz/ cisla/0/02/020100/obyvatel.htm

Populační data získána z webového portálu ONS - pro rok 2001. Ons.gov.uk [online]. 2019 [cit. 2019-09-17]. Dostupné z: http://www.ons.gov.uk/ons/rel/census/census -2001-key-statistics/local-authorities-in-england-and-wales/local-authorities-ks06--ethnic-group.xls

Press release: Prime Minister launches police recruitment drive. GOV.UK [online]. 2019 [cit. 2019-09-17]. Dostupné z: https://www.gov.uk/government/news/prime-minister-launches -police-recruitment-drive

Project Ireland 2040. Gov.ie [online]. 2019 [cit. 2019-09-16]. Dostupné z: https://www.gov.ie/en/campaigns/09022006 -project-ireland-2040/?referrer=/en/project-ireland -2040

Race and crime in the United Kingdom. Wikipedia.org: the free encyclopedia [online]. 2019 [cit. 2019-09-16]. Dostupné z: https://en.wikipedia.org/wiki/Race_and_crime_in_the _United_Kingdom\#Statistics

SHAW, Danny. Ten charts on the rise of knife crime in England and Wales. BBC News [online]. 2019 [cit. 2019-09-17]. Dostupné z: https://www.bbc.com/news/uk-42749089

The New York Declaration for Refugees and Migrants Answers to Frequently Asked Questions. UNHCR [online]. 2019 [cit. 2019-09-17]. Dostupné z: https://www.unhcr.org/ 584689257.pdf

Urban Area Summary Results For Local Authorities. Gov.scot [online]. (C2019 [cit. 2019-09-17]. Dostupné z: http://www. 
ons.gov.uk/ons/rel/census/census-2001-key-statistics/ urban-area-summary-results-for-local-authorities/urban -area-summary-results-for-local-authorities-ks06--ethnic -group.xls

Vláda navrhla významné posílení bezpečnosti České republiky. Bezpečnostní informační služba [online]. 2018 [cit. 2019-09-17]. Dostupné z: https://www.bis.cz/aktuality/ vlada-navrhla-vyznamne-posileni-bezpecnosti-ceske -republiky-6ff3db23.html 